УДК 331.3

DOI: https://doi.org/10.37320/2415-3583/12.29

\author{
Прядко I.B. \\ старший викладач кафедри економічної теорії \\ та міжнародної економіки, \\ Чорноморський національний університет імені Петра Могили \\ ORCID: https://orcid.org/0000-0001-6664-0914
}

Пікінер М.В.

студентка,

Чорноморський національний університет імені Петра Могили ORCID: https://orcid.org/0000-0002-3441-6528

\title{
АВТОМАТИЗАЦІЯ ВИРОБНИЦТВА В УКРАЇНІ: СТАН ТА ОСОБЛИВОСТІ
}

У статті розглянуто вплив автоматизаиії виробництва (Індустрія 4.0) на ринок праці. Актуальність вибраної теми зумовлюється кардинальними змінами на ринку праці через Індустрію 4.0, яка викликає «перебудову» професій. В процесі дослідження здійснено аналіз впливу процесу автоматизації на ринок праці. Визначено особливості становлення автоматизації в Україні. Досліджено динаміку показника продуктивності праці. Визначено основні фактори невеликих темпів приросту продуктивності праці на українських ринках під час впровадження «Індустрії 4». Досліджено залежність між продуктивністю праці та заробітною платою в Україні. Проаналізовано показник рівня участі населення в робочій силі. На основі світового досліду зроблено висновок щчодо галузей виробниџтва, яких Індустрія 4.0 торкнеться передусім.

Ключові слова: Індустрія 4.0, автоматизація виробництва, роботизація, технологічне безробіття, інноваиійний розвиток регіону.

Постановка проблеми. За досягненнями Четвертої індустріальної революції ми спостерігаємо просто зараз. Вона розпочалась у кінці першого десятиріччя XXI століття, характеризуючись повною автоматизацією виробництва. Провідну роль набувають інтернет-технології, які дають робітнику змогу мати зв'язок 3 машинами. Таке виробництво дає змогу створювати більшу кількість товарів без підвищення ціни. Синонімом до Четвертої революції є поняття «Індустрія 4.0». Вона була проголошена у 2011 році урядом Німеччини, поставивши на меті розширення застосування інформаційних технологій, щоби сприяти більшому розвитку промислового виробництва. Однією з цілей Індустрії $4.0 €$ є інноваційний розвиток.

Автоматизація виробництва має переваги й недоліки, адже вона знищує робочі місця, призводить до зменшення кількості працюючих та одночасно піднімає продуктивність виробництва в рази, але процес автоматизації в Україні має свої особливості, які пояснюються специфікою менталітету та економічним станом країні.

Аналіз останніх досліджень і публікацій. Автоматизацію виробництва та вплив інноваційних технологій на робочі місця досліджували американські фахівці Д. Аутор і Д. Дорн разом із Брюссельською європейською і глобально-економічною лабораторією (BRUEGEL) [1], а також Е. Брінолфссон, Е. Макафі [2], Дж.Б. Тейлор, А. Уірапан [3], А.В. Коваленко, Е.С. Калінська [4] та інші фахівці. Їх більшість звертає увагу на можливе посилення соціальної та фінансової нерівності у світі через порушення роботи ринків праці. Автоматизація призведе до витіснення людей з ринків праці, створиться передумова безробіття та збільшиться розрив між прибутковістю капіталу та прибутковістю праці, відбудеться підвищення заробітної плати висококваліфікованим працівникам. Таким чином, наукові та практичні дослідження цього питання вказують на неоднозначний вплив Індустрії 4.0 на економічне зростання країни та регіону.

Мета статті полягає у діагностиці стану впровадження автоматизації «Індустрія 4.0» на український ринок праці та визначенні особливостей цього процесу.

Виклад основного матеріалу. Однією з основних переваг автоматизації виробництва $є$ суттєве підвищення продуктивності праці. Вона відображає співвідношення між кількістю виробленої продукції та кількістю робочого часу, який знадобився для ії вироблення.

Разом зі збільшенням продуктивності збільшується кількість товарів та послуг, що підвищує рівень життя людей за рахунок більшого споживання. Важливо розрізняти продуктивність праці та продуктивність робітника, яка вимірює продуктивність окремої людини.

Рівень продуктивності праці в Україні тісно пов'язаний з її конкурентоспроможністю та економічним зростанням. Розглянемо динаміку ефективності людського капіталу у виробничому процесі (табл. 1) для оцінювання показника з часом. Показник відображається за допомогою ВВП (за паритетом купівельної спроможності) в розрахунку на одного зайнятого.

Протягом останніх десяти років показник має тенденцію до зростання, проте значного приросту не спостерігається. У 2019 році порівняно з 2009 роком продуктивність праці одного зайнятого зросла на 17\%. Такий повільний приріст зумовлений низкою причин, однією 3 яких $\epsilon$ тяжке кризове становище країни, в якому вона перебувала досить тривалий час. Причинами незадовільних темпів приросту продуктивності також $\epsilon$ наявність у країні протягом тривалого часу «тіньової» економіки, демографічна ситуація, неефективні стратегії розвитку, відсутність достовірних статистичних даних, які б дали змогу проаналізувати ситуацію. Крім цього, те, що в Україні за десять років не відбулося істотного розвитку, говорить про неефек- 
Таблиця 1 - Продуктивність праці в Україні, тис. дол. США

\begin{tabular}{|c|c|c|c|c|c|c|c|c|c|c|c|}
\hline Показник & $\begin{array}{c}\mathbf{2 0 0 9} \\
\text { рік }\end{array}$ & $\begin{array}{c}\mathbf{2 0 1 0} \\
\text { рік }\end{array}$ & $\begin{array}{c}\mathbf{2 0 1 1} \\
\text { рік }\end{array}$ & $\begin{array}{c}\mathbf{2 0 1 2} \\
\text { рік }\end{array}$ & $\begin{array}{c}\mathbf{2 0 1 3} \\
\text { рік }\end{array}$ & $\begin{array}{c}\mathbf{2 0 1 4} \\
\text { рік }\end{array}$ & $\begin{array}{c}\mathbf{2 0 1 5} \\
\text { рік }\end{array}$ & $\begin{array}{c}\mathbf{2 0 1 6} \\
\text { рік }\end{array}$ & $\begin{array}{c}\mathbf{2 0 1 7} \\
\text { рік }\end{array}$ & $\begin{array}{c}\mathbf{2 0 1 8} \\
\text { рік }\end{array}$ & $\begin{array}{c}\mathbf{2 0 1 9} \\
\text { рік }\end{array}$ \\
\hline Продуктивність праці & 17,4 & 18,0 & 18,9 & 19,2 & 18,9 & 19,6 & 17,7 & 18,4 & 19,0 & 19,7 & 20,5 \\
\hline
\end{tabular}

Джерело: сформовано на основі джерела [5]

Таблиця 2 - Динаміка номінальної та реальної заробітної плати в Україні, \%

\begin{tabular}{|c|c|c|c|c|}
\hline \multirow{2}{*}{ Рік } & \multicolumn{2}{|c|}{ Номінальна } & \multicolumn{2}{|c|}{ Реальна } \\
\cline { 2 - 5 } & до попереднього року & $\begin{array}{c}\text { грудень до грудня } \\
\text { попереднього року }\end{array}$ & до попереднього року & $\begin{array}{c}\text { грудень до грудня } \\
\text { попереднього року }\end{array}$ \\
\hline 2010 & 117,6 & 117,9 & 110,2 & 110,5 \\
\hline 2011 & 117,7 & 116,2 & 108,7 & 111,0 \\
\hline 2012 & 114,8 & 110,5 & 114,4 & 11,1 \\
\hline 2013 & 107,9 & 107,2 & 108,2 & 86,4 \\
\hline 2014 & 106,0 & 110,4 & 93,5 & 90,1 \\
\hline 2015 & 120,5 & 130,4 & 79,8 & 111,6 \\
\hline 2016 & 123,6 & 123,8 & 109,0 & 118,9 \\
\hline 2017 & 137,1 & 135,5 & 119,1 & 109,7 \\
\hline 2018 & 124,8 & 120,5 & 112,5 & 111,3 \\
\hline 2019 & 118,4 & 116,0 & 109,8 & \\
\hline
\end{tabular}

Джерело: сформовано на основі джерела [6]

тивне використання трудового потенціалу. Перш за все це пов'язано з відсутністю певних вимог до професійної підготовки або відсутністю можливості отримати цю підготовку. Також слід зазначити, що важливою умовою зростання продуктивності праці $€$ використання інформаційних технологій. Аналіз даних офіційного сайту Державної служби статистики України [6] дав можливість зробити такі висновки стосовно 2018 року порівняно з 2010 роком:

- кількість працівників, задіяних у виконанні наукових досліджень і розробок, зменшилась на 23\%;

- витрати на виконання наукових досліджень і розробок зросли на $118 \%$;

- загальний обсяг витрат на інноваційну діяльність зріс на 51\%;

- впровадження інновацій на промислових підприємствах зменшилась на $2 \%$.

Аналіз зазначених даних свідчить про слабкий попит на технології Індустрії 4.0. Можна зробити припущення, що українські підприємці ще не бачать перспектив програми, тому інвестиції в ці технології не зростають. Водночас скорочується кількість робітників, які б могли зробити досягнення у сфері інноваційного розвитку й підвищити продуктивність. Це можна охарактеризувати поняттям «відплив умів».

Одночасно ми бачимо збільшення витрат на наукові дослідження та інноваційну діяльність. Ці витрати можуть бути пов'язані з рухом «Індустрія 4.0 в Україні». Нині рух сприяв відкриттю трьох Центрів 4.0. Кожен 3 центрів має 4 основні напрями діяльності, такі як нетворкінг, створення нових навчальних курсів, просвіта ринку й розвиток науково-дослідних робіт [7]

Важливою складовою частиною підвищення продуктивності праці є мотивація персоналу. Аналіз динаміки табл. 1 свідчить про те, що в Україні мотивація до підвищення продуктивності праці перебуває на досить слабкому рівні, тому країна потребує створення ефективних систем мотивації персоналу на підприємствах.
Найважливішою складовою частиною матеріальної мотивації є заробітна плата (табл. 2).

Аналіз табл. 2 свідчить про те, що за зазначений проміжок часу номінальна заробітна плата щорічно зростала в середньому на $0,08 \%$. Одночасно реальна заробітна плата зменшувалась щорічно на $0,04 \%$. Таким чином, можна зробити висновок, що підвищення мотивації до праці через стимулювання приросту заробітної плати не відбувається.

Таким чином, в процесі автоматизації в Україні поки не спостерігається суттєвих приростів підвищення продуктивності. Насамперед цей факт можна пояснити недостатньою мотивацією до праці з боку працюючих через відсутність матеріальних стимулів.

Відомо, що процес автоматизації виробництва зазвичай призводить до зменшення кількості працюючих. Розглянемо рівень участі населення України в робочій силі (табл. 3).

Аналіз зазначених даних свідчить про тенденцію щодо скорочення частки населення в робочій силі (на 0,22\% щорічно). Такий факт можна пояснити невідповідністю професійних навичок людей до вимог роботодавців, великою кількістю низько кваліфікованих професій, працю яких можуть замінити досягненнями Індустрії 4.0. Нині спостерігається зменшення кількості вакансій на ринку праці. За даними Державної служби статистики України у 2019 році в робочій силі частка жінок складала 49,2\%, а частка чоловіків $64,8 \%$. Крім цього, більша частина працюючих $(57,7 \%)$ перебувала в міській місцевості [6].

Таким чином, аналіз табл. 1-3 дає змогу зробити висновок, що темпи зростання реальної заробітної плати значно вищі, ніж темпи зростання продуктивності праці. Можна сказати, що заробітна плата слабо залежить від кількості та якості праці, тому більш ефективна праця не дає більших доходів. Хоча з 2015 року продуктивність продовжувала зростати, вона все ще відставала від заробітної плати до 2019 року. Відста- 
Таблиця 3 - Участь населення в робочій силі в Україні, \%

\begin{tabular}{|c|c|c|c|c|c|c|c|c|c|c|c|}
\hline Показник & $\begin{array}{c}\mathbf{2 0 0 9} \\
\text { рік }\end{array}$ & $\begin{array}{c}\mathbf{2 0 1 0} \\
\text { рік }\end{array}$ & $\begin{array}{c}\mathbf{2 0 1 1} \\
\text { рік }\end{array}$ & $\begin{array}{c}\mathbf{2 0 1 2} \\
\text { рік }\end{array}$ & $\begin{array}{c}\mathbf{2 0 1 3} \\
\text { рік }\end{array}$ & $\begin{array}{c}\mathbf{2 0 1 4} \\
\text { рік }\end{array}$ & $\begin{array}{c}\mathbf{2 0 1 5} \\
\text { рік }\end{array}$ & $\begin{array}{c}\mathbf{2 0 1 6} \\
\text { рік }\end{array}$ & $\begin{array}{c}\mathbf{2 0 1 7} \\
\text { рік }\end{array}$ & $\begin{array}{c}\mathbf{2 0 1 8} \\
\text { рік }\end{array}$ & $\begin{array}{c}\mathbf{2 0 1 9} \\
\text { рік }\end{array}$ \\
\hline $\begin{array}{c}\text { Участь } \\
\text { населення }\end{array}$ & 54,9 & 55,0 & 55,2 & 54,9 & 55,6 & 54,3 & 54,6 & 54,4 & 54,2 & 53,9 & 53,7 \\
\hline
\end{tabular}

Джерело: сформовано на основі джерела [8]

Таблиця 4 - Зайняте населення за професійними групами у 2010-2019 роках, тис. осіб

\begin{tabular}{|l|c|c|c|c|c|c|c|}
\hline \multicolumn{1}{|c|}{ Показник } & $\mathbf{2 0 1 3}$ рік & $\mathbf{2 0 1 4}$ рік & $\mathbf{2 0 1 5}$ рік & $\mathbf{2 0 1 6}$ рік & $\mathbf{2 0 1 7}$ рік & $\mathbf{2 0 1 8}$ рік & $\mathbf{2 0 1 9}$ рік \\
\hline Усього зайнятих (15-70 років) & 19314,2 & 18073,3 & 16443,2 & 16276,9 & 16156,4 & 16360,9 & 16578,3 \\
\hline $\begin{array}{l}\text { Законодавці, керівники, } \\
\text { менеджери }\end{array}$ & 1495,0 & 1442,5 & 1299,0 & 1259,7 & 1234,9 & 1320,4 & 1330,3 \\
\hline Професіонали & 2866,7 & 3097,7 & 2903,7 & 2906,0 & 2890,2 & 3012,3 & 2976,9 \\
\hline Фахівці & 2157,2 & 2213,8 & 1978,3 & 1909,3 & 1831,1 & 1832,8 & 1918,8 \\
\hline Технічні службовці & 616,4 & 586,8 & 521,2 & 485,4 & 477,1 & 474,8 & 531,2 \\
\hline $\begin{array}{l}\text { Працівники сфери торгівлі та } \\
\text { послуг }\end{array}$ & 2949,4 & 2874,5 & 2691,2 & 2734,7 & 2726,8 & 2739,8 & 2757,8 \\
\hline $\begin{array}{l}\text { Кваліфіковані робітники } \\
\text { сільського та лісового } \\
\text { господарств, рибальства }\end{array}$ & 165,2 & 173,7 & 155,8 & 138,7 & 135,8 & 120,9 & 160,7 \\
\hline $\begin{array}{l}\text { Кваліфіковані робітники з } \\
\text { інструментом }\end{array}$ & 2306,4 & 2320,3 & 2017,0 & 1946,5 & 1934,1 & 1902,0 & 2065,8 \\
\hline $\begin{array}{l}\text { Робітники з обслуговування } \\
\text { технологічного устаткування } \\
\text { та машин }\end{array}$ & 2236,1 & 2180,8 & 2062,9 & 1849,2 & 1821,2 & 1785,0 & 1826,9 \\
\hline Найпростіші професії & 4577,1 & 3301,1 & 3027,8 & 3075,4 & 3141,4 & 3131,0 & 2989,5 \\
\hline
\end{tabular}

Джерело: сформовано на основі джерела [6]

вання продуктивності від оплати праці призводить до погіршення інфляційного стану. Така ситуація є можливою за рахунок відсутності або нестачі кваліфікованих робітників чи потрібного устаткування. Як було зазначено раніше, велика частина підприємств не впроваджує інновації, крім цього, спостерігається «відплив умів», які б змогли покращити інноваційний стан країни.

Стає зрозумілим необхідність підвищення продуктивності праці та створення зайнятості населення завдяки безпечним умовам праці, мотивації, розвитку, професійної підготовки та ефективного використання знань. Однак вакантних місць стає все менше, водночас підвищуються вимоги до кандидатів, оскільки вони мають створити конкуренцію інноваційним змінам у світі завдяки Індустрії 4.0. Хоча зараз багато підприємств ще не бачать усіх можливостей технологій 4.0, в майбутньому вони не зможуть ефективно існувати на ринку без їхього використання. Якщо раніше зростання продуктивності супроводжувалося зростанням заробітної плати, то сьогодні продуктивність зростає 3 інших причин. Послаблення цього зв'язку наштовхує економістів на прогнозування майбутніх змін на ринку праці. Безперечним та очікуваним багатьма економістами явищем $є$ масове безробіття. 3 огляду на Індустрію 4.0 йдеться про технологічне безробіття.

Здійснимо аналіз кількості працюючих за професійними групами (табл. 4).

3 табл. 4 можна побачити, що для ринку праці за 2013-2019 роки характерне падіння чисельності зайнятого населення віком 15-70 років $з 19314,2$ тис. осіб до 16 578,3 тис. осіб відповідно. Скорочення чисельності зайнятих спостерігається у всіх групах, крім професі- оналів, де має місце зростання на 3,8\%. Особливого падіння зазнали групи найпростіших професій (-35\%) та робітників 3 обслуговування технічного устаткування $(-18 \%)$.

Отже, зайнятість населення в Україні має тенденцію до зменшення. Слідуючи за змінами на ринку праці, можемо зробити висновок, що на Україну хоч трохи, але впливають світові тенденції. Найпростіші професії та професії середніх класів продовжують втрачати працюючих через постійну автоматизацію виробництва.

За словами представників аналітичної компанії “Oxford Economics” кожний новий промисловий робот скорочує до 1,6 робочих місць, а найменш кваліфіковані верстви страждають більше [9].

Процес Індустрії 4.0 у світі спричинив величезне зростання продажів промислових роботів у секторі високоавтоматизованих автомобілів, тому країни із сильним зростанням автомобільної промисловості матимуть високу щільність роботів. Промислові роботи також проникають у металообробну та машинобудівну промисловості, гумову й пластмасову, а також харчову промисловість і виробництво напоїв. Сьогодні є багато країн, які проявляють інтерес до промислових роботів, наприклад Південна Корея, Сінгапур, Німеччина, Японія, Швеція, Данія, США, Італія, Бельгія і Тайвань [10]. Оскільки Україна відстає за рівнем технологічного розвитку від зазначених країн, з довготривалим лагом можна зробити екстраполяцію світових реалій на українські галузі, які перш за все зазнають скорочення кількості працюючих через автоматизацію виробництва.

Проаналізувавши наявні тенденції, можемо зробити висновок, що процес «Індустрія 4.0», попри свої переваги, має суттєві мінуси, які є невід'ємною час- 
тиною інтенсивного типу економічного зростання. Це підвищення витрат на впровадження нових технологій та скорочення частки працюючих. Однак це явище відбудеться переважно за рахунок працівників низької кваліфікації. Водночас виникає попит на більш освічених людей, що буде зумовлене появою нових професій.

Висновки. Сьогодні процес автоматизації виробництва «Індустрія 4» перебуває у своєму початковому стані, оскільки досить невелика частка виробників розуміє його переваги й має кошти на його впровадження.

Процес автоматизації в Україні характеризується повільним зростанням з низки причин, які існують у нашій країні вже досить тривалий час. Це можна пояснити неефективним використанням трудового потенціалу, слабким попитом вітчизняних підприємств на технології Індустрії 4.0, а також наявністю «відпливу умів».

Рівень участі населення в робочій силі поки не зазнав значних змін показника, що пояснюється великою часткою неформально зайнятих людей, зокрема в оптовій та роздрібній торгівлі, в сільському господарстві. Отже, робоча сила характеризується великою кількістю низько кваліфікованих людей, працю яких можуть замінити досягнення Індустрії 4.0
В нашій країні зростання заробітної плати не супроводжується зростанням продуктивності праці. Це може пояснити відсутність або нестача кваліфікованих робітників та потрібного устаткування. Україна потребує підвищення продуктивності та створення умов зайнятості населення. Сьогодні продуктивність зростає 3 інших причин. За останні роки для ринку праці характерне падіння чисельності зайнятого населення у всіх групах, крім професіоналів. Найбільше скорочення показника спостерігається серед найпростіших професій.

Порівнюючи Україну з іншими країнами, можемо зробити висновок, що наша країна поки що відстає від світових тенденцій, але все ж таки відчуває їхній вплив. Наш ринок праці відчує зміни впровадження автоматизованого виробництва набагато пізніше, ніж інші європейські країни. Економічні процеси гальмує велика кількість некваліфікованих робітників. Відповідно, проблеми, які можуть призвести до технологічного безробіття в нашій країні, можна вирішити шляхом концентрації уваги на освіті, яка характеризується невтішною динамікою, та перекваліфікації людей. Ринок праці потребує підготовки людей до нових технологій, фінансування наукових заходів та досліджень, наявності фахівців та професіоналів.

\section{Список використаних джерел:}

1. Аранжин В.В. Взаимосвязь заработной платы и производительности труда: тенденции в условиях цифровизации экономики. Экономика труда. 2019. № 1. С. 524-534.

2. Chappelow J. Labor Productivity. URL: https://www.investopedia.com/terms/l/labor-productivity.asp (дата звернення: 25.05.2020).

3. Taylor B., Greenlaw S. Labor productivity and economic growth. URL: https://opentextbc.ca/principlesofeconomics/ chapter/20-2-labor-productivity-and-economic-growth (дата звернення: 25.05.2020).

4. Коваленко А.В., Калинская Е.С., Гелета И.В. Направления роста производительности труда. Экономика устойчивого развития. 2014. № 3. С. 99-104.

5. International Labour Organization. Statistics on labour productivity. URL: https://ilostat.ilo.org/topics/labour-productivity (дата звернення: 25.05.2020)

6. Державна служба статистики України. URL: http://www.ukrstat.gov.ua (дата звернення: 25.05.2020).

7. Відкриття Центру 4.0 в КПІ. Індустрія 4.0 в Україні. URL: https://industry4-0-ukraine.com.ua/2019/04/22/v\%d1\%96dkrittyacentru-4-0-v-kp\%d1\%96-zv\%d1\%96t/\#more-9746 (дата звернення: 25.05.2020).

8. The World Bank Group. URL: https://www.worldbank.org (дата звернення: 25.05.2020)

9. Robots 'to replace up to 20 million factory jobs' by 2030. URL: https://www.bbc.com/news/business-48760799 (дата звернення: 3.05 .2020$)$.

10. Top 10 automated countries of 2019. Analytics Insight. URL: https://www.analyticsinsight.net/top-10-automatedcountries-of-2019 (дата звернення: 25.05.2020).

11. The Countries With The Highest Density Of Robot Workers. URL: https://www.statista.com/chart/13645/the-countries-withthe-highest-density-of-robot-workers (дата звернення: 25.05.2020).

12. Technological unemployment. URL: https://www.economicshelp.org/blog/glossary/technological-unemployment (дата звернення: 25.05.2020).

\section{References:}

1. Aranzhyn V.V. (2019). Vzaymosvjazj zarabotnoj platy y proyzvodyteljnosty truda: tendencyy v uslovyjakh cyfrovyzacyy ekonomyky [The relationship between wages and labor productivity: trends in the digitalization of the economy]. Ekonomyka truda, № 9, pp. 524-534.

2. Chappelow J. (2020). Labor Productivity. Retrieved from: https://www.investopedia.com/terms/l/labor-productivity.asp (accessed: 25 May 2020).

3. Taylor B. \& Greenlaw S. (2020). Labor productivity and economic growth. Retrieved from: https://opentextbc.ca/ principlesofeconomics/chapter/20-2-labor-productivity-and-economic-growth (accessed: 25 May 2020).

4. Kovalenko A., Kalynskaja E. \& Gheleta Y. (2014). Napravlenyja rosta proyzvodyteljnosty truda [Directions of growth of labor productivity]. Ekonomyka ustojchyvogho razvytyja, № 33, pp. 99-104.

5. International Labour Organization (2020). Official web-site. Retrieved from: https://ilostat.ilo.org/topics/labour-productivity (accessed: 25 May 2020).

6. State Statistics Service of Ukraine (2020). Official web-site. Retrieved from: http://www.ukrstat.gov.ua [in Ukrainian] (accessed: 25 May 2020).

7. Opening of Center 4.0 in KPI. Industry 4.0 in Ukraine (2019). Retrieved from: https://industry4-0-ukraine.com.ua/2019/04/22/ v\%d1\%96dkrittya-centru-4-0-v-kp\%d1\%96-zv\%d1\%96t/\#more-9746 (accessed: 25 May 2020).

8. The World Bank Group (2020). Official web-site. Retrieved from: URL: https://www.worldbank.org (accessed: 25 May 2020 ). 
9. Robots 'to replace up to 20 million factory jobs' by 2030 (2020). Retrieved from: https://www.bbc.com/news/business-48760799 (accessed: 03 May 2020).

10. Top 10 automated countries of 2019. Analytics Insight (2019). Retrieved from: https://www.analyticsinsight.net/top-10automated-countries-of-2019 (accessed: 25 May 2020).

11. The Countries With The Highest Density Of Robot Workers (2019). Retrieved from: https://www.statista.com/chart/13645/ the-countries-with-the-highest-density-of-robot-workers (accessed: 25 May 2020).

12. Technological unemployment (2019). Retrieved from: https://www.economicshelp.org/blog/glossary/technologicalunemployment (accessed: 25 May 2020).

Priadko Iryna, Pikiner Marina Petro Mohyla Black Sea National University

\section{PRODUCTION AUTOMATION IN UKRAINE: STATE AND FEATURES}

The relevance of the chosen topic is explained by the radical changes in the labor market through Industry 4.0 , which, in turn, causes a "restructuring" of professions. This is due to the introduction of automated production, which creates automated jobs and promotes economic growth. Industry 4.0 has become a driving force in today's economy, changing everything in people's lives and businesses, and creating the new types of economies. It is evolving very fast, confidently leading to downsizing, and affects every industry. The purpose of the article is the researches of the consequences of changes in the labor market through the introduction of automation "Industry 4.0". Automation is gradually leading to the fact that machines are displacing many people from the labor market, creating a redistribution of intellectual resources. The special role of information technology is to solve the problem of increasing productivity in production. Thus Industry 4.0 opens up great opportunities. The article is analyzed the impact of automation on the labor market, identified the relationship between productivity and wages in Ukraine, identified existing trends in robotics, identified industries that Industry 4.0 will be affected in the first place. It was identified that the country's economic growth is influenced by the level of labor productivity, which is characterized by slow growth due to a number of reasons that have existed in our country for some time. This fact is explained by inefficient use of labor potential, weak demand of domestic enterprises for the technology of Industry 4.0. The level of population participation in the labor force has not changed significantly. It can be explained by the large proportion of informally employed people. The workforce is characterized by a large number of low-skilled people, whose work can be replaced by the achievements of Industry 4.0. In Ukraine wage growth is not accompanied by productivity growth. Ukraine needs to increase productivity and create employment. The government should, create the necessary conditions for the emergence of new professions to get new workplaces. The article is important in the context of research on the mechanisms of regulation of innovation activities of the country and regions.

Key words: Industry 4.0, production automation, robotics, technological unemployment, innovative development of the region.

JEL classification: J21, J23, L 51, M11, O10 